\title{
Comparative Study of IGFBP Properties in Toad and Rat Sera
}

\author{
A. M. Cortizo, ${ }^{* 1}$ D. Braziunas, ${ }^{*}$ H. Jasper, $\dagger^{\dagger}{ }^{2}$ and J. J. Gagliardino*,2 \\ *CENEXA, Centro de Endocrinologia Experimental y Aplicada (UNLP-CONICET), 60 y I20 (I900) La \\ Plata, Argenina; and †CEDIE, Centro de Investigaciones Endocrinológicas, Ditisión de Endocrinología, \\ IIospital General de Niños "Ricardo Gutiérrez," Gallo 1330 (1400) Buenos Aires, Argentina
}

Accepted July 14, 1993

\begin{abstract}
The levels of IGF-I have been simultaneously measured by radioimmunoassay in samples of the toad Bufo arenarum and of normal male Wistar rats. In addition, the different fractions of IGF-I binding proteins (IGFBP) and their binding properties have been identified by ligand blot and Scatchard analysis in the serum of both species. In the toad, we have measured levels of IGF-1 $(2.78 \pm 0.48 \mathrm{ng} / \mathrm{ml})$ similar to those previously reported in amphibians but far below those found in rats. IGFBP levels were estimated at $129 \pm 23$ and $4249 \pm 321 \mathrm{pg} / \mathrm{ml}$ in toad and rat serum samples. Two main IGFBP fractions of $30-34 \mathrm{kDa}$, accompanied by a ninor component of $24 \mathrm{kDa}$ and seldom by another of $40 \mathrm{kDa}$. were identified in toad serum. In rat serum-as already reported-three bands of 40,30 , and 24 kDa were identified, the first being the main component and the last the minor one. The Scatchard analysis of a competitive binding assay showed two types of binding sites in toad serum: one of high affinity-low capacity $\left(K_{\mathrm{a}_{1}}=1.6 \times 10^{10} \mathrm{M}^{-1} ; R_{1}=1.2 \times 10^{-11} \mathrm{M}\right)$ and another with low affinity-high capacity $\left(K_{\mathrm{a}_{2}}=1.9 \times 10^{8} \mathrm{M}^{-1} ; R_{2}=1.9 \times 10^{-10} \mathrm{M}\right)$. The percentage fraction of these binding sites occupied by IGF-I was $13.5 \%$. The figures for $K_{1}$ and $K_{2}$ were lower and those for $R_{1}$ and $R_{2}$ were higher in rat than in toad serum. The percentage fraction of occupied rat $1 \mathrm{GF}$ binding sites was $3.6 \%$. The $1 \mathrm{GF}$ carrier levels $\left(\mathrm{IGFBP}_{s}\right.$ ) estinated in our laboratory in samples of rat and toad serum gave figures that were almost 33 times lower in the latter than in the former. Hence, the fraction of free and bound IGF-I in toad and rat blood might be different. Our results provide new evidence of the presence and the properties of IGFBP in amphibians, confirming the wide distribution of this carrier among different species and its possible role as modulator of IGF-l biological effects. (1) 1993 Academic Press, inc.
\end{abstract}

Insulin-like growth factor I (IGF-I), a well-known growth-promoting agent (Van Wyk, 1984), mediates the action of the growth hormone in several target tissues through initial interaction with specific Type I-IGF cellular receptors (Flier et al., 1986). The endocrine pancreas would be among such IGF-I target tissues (Swenne $e t$ al., 1989).

In vivo, IGF-1 circulates in plasma in association with specific high-affinity binding proteins (IGFBP) (Rechler and Nissley, 1990). These IGFBP do not act as merely

\footnotetext{
${ }^{1}$ Memher of the Carrera del Investigador CICPBA.

${ }^{2}$ Member of the Carrera del Investigator CONICET.
}

passive transporters of the hormone, but rather modulate IGF-I action by altering its interaction with those specific cellular receptors (Rutanen, 1990; Yateman et al., 1993). It has also been suggested that the IGFBP could alter not only the effective concentration of IGF available for binding to its receptors but also the number of potential IGF-I binding sites on the plasma membrane of the target cell (McCusker et al., 1991).

Since many years ago, our group has been involved in the study of endocrine pancreas function and its growth control. Consequently, we have been looking for suitable models for studying such processes both in vivo and in vitro. We have recently 
found that the pancreas of the toad (Bufo arenarum) has some properties-such as an active cellular growth and duplication in the adult - that could become a useful in vivo model for our studies. Hence, we would like to characterize in this model the relationship between the IGF-IGFBP system and the growth of the endocrine cells in the pancreas. For this purpose we have currently studied the levels of IGF-I and IGFBP in the serum of the toad Bufo arenarum and compared them with those measured in normal rats. We have also attempted to identify the different serum IGFBP fractions and their binding properties in both species.

\section{MATERIALS AND METHODS}

Materials. Rabbit polyclonal IGF-I antibody (UBK 487) was kindly provided by Dr. L. E. Underwood (Division of Pediatric Endocrinology, University of North Carolina, Chapel Hill, NC); recombinant human IGF-I (hIGF-I) was purchased from Bachem Inc. (Torrance, $\mathrm{CA})$; ${ }^{125} \mathrm{I}$ was obtained from New England Nuclear (Boston, MA); ${ }^{125} \mathrm{I}_{-} \mathrm{IGFBP}_{3}$ was kindly provided by Dr. Verghese from Diagnostic Systems Laboratories Inc. (Webster, TX); glucose GOD-PAP kit for glucose determination was kindly provided by Boehringer Mannheim Argentina (Buenos Aires, Argentina); human immunoglobulin was kindly provided by Gador (Buenos Aires, Argentina); fatty-acid-free bovine serum albumin, X-Omat Kodak Film, prestained molecular weight marker proteins and other reagents of the purest available grade were obtained from Sigma Chemical Co. (St. Louis, MO).

Male adult specimens of Bufo arenarum Hensel toads of about $130 \mathrm{~g}$ body weight, captured during our autumn season in La Plata (Argentina) were used in this study. The animals were maintained in a suitable enclosure containing water and insects. Their diet was supplemented with mealworms. To perform various experiments, the toads were pithed by severing the spinal cord and blood samples $(2-3 \mathrm{ml})$ were later obtained by cardiac puncture.

Normal male Wistar rats of about $250 \mathrm{~g}$ body weight were used as blood donors. These animals had free access to tap water and standard commercial chow diet. Blood samples $(3 \mathrm{ml})$ were obtained from the retroorbital plexus under light ether anesthesia.

After being allowed to clot, blood samples were centrifuged $(1000 \mathrm{~g}$ for $15 \mathrm{~min})$ at $4^{\circ}$ and stored at $-20^{\circ}$ for no longer than 1 week until the performance of different assay procedures.

Serum glucose and protein levels were determined by the glucose oxidase and Bradford's (1976) methods, respectively.

Total serum IGF-I was measured in single samples by radioimmunoassay (Furlanetto et al., 1977) after extraction of the IGFBP with a mixture of formic acid-Tween 20-acetone (Bowsher et al., 1991). Each sample was measured in triplicates; recovery experiments performed with this procedure show a $100 \%$ value. For the assay procedure the UBK 487 IGF-I polyclonal antibody (diluted 1:18,000) was used and hIGF-I was employed for standards and tracer. hIGF-I was iodinated with a specific activity of $400-450 \mu \mathrm{Ci} /$ mg using the chloramine T procedure (D'Ercole et al., 1976). RIA data were analyzed using the RIA Data Reduction Program for the IBM-PC (Rodbard, 1984). The intra- and interassay coefficients of variation were 10.9 and $13.0 \%$, respectively.

Although Pancak-Roesler and Lee (1990) using the same IGF-I antibody as we did demonstrated that after acid-ethanol treatment toad plasma and purified hIGF-I standards gave parallel displacement curves, we repeated such cross-reactivity study under our assay conditions. Figure 1 shows that in the range of 20 to $50 \mathrm{pg} /$ tube of our standard curve, appropriate dilution of toad serum samples and the hIGF-I standards produced a parallel displacement of the tracer. Consequently, and for assay purposes, toad serum samples were carefully diluted in order to read all of them within such concentration range.

IGFBP were studied using the ligand blotting technique described by Hossenlopp et al. (1986). For that purpose, $30 \mu \mathrm{l}$ of serum samples were mixed with a four-times concentrated sample buffer ( $62.5 \mathrm{mM}$ Tris$\mathrm{HCl}, \mathrm{pH} 6.8,2 \% \mathrm{SDS}, 10 \%(\mathrm{v} / \mathrm{v})$ glycerol and $0.001 \%$ bromophenol blue) (Laemmli, 1970) under nonreducing conditions and boiled for $3 \mathrm{~min}$ before being loaded onto a $12.5 \%$ SDS-polyacrylamide gel. Samples were electrophoresed at $200 \mathrm{~V}$ until the dye front reached the bottom of the gel. Prestained molecular weight

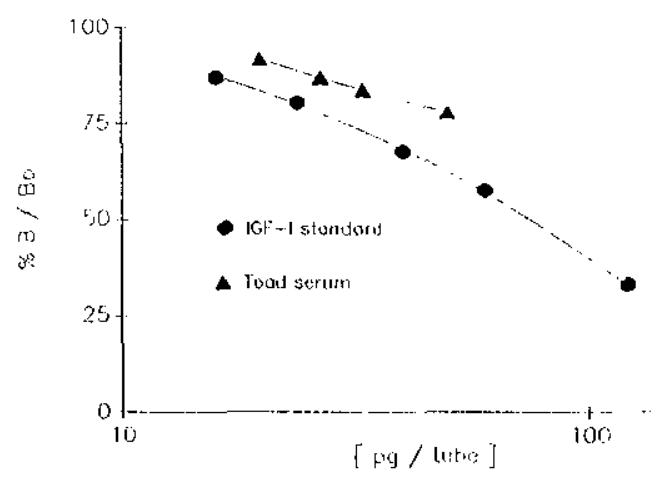

F1G. 1. Displacement curves showing parallelism between hIGF-I and different volumes $(6,8$, and $10 \mu \mathrm{l})$ of toad serum. (O) hIGF-I; and (A) toad plasma. 
marker proteins were run in a parallel lane. Proteins were transferred to nitrocellulose membranes at room temperature in a $15 \mathrm{mM}$ Tris base-120 mM glycine buffer, $\mathrm{pH} 8.3$, containing $5 \%(\mathrm{v} / \mathrm{v})$ methanol. Electroblotting was performed under a constant current at $100 \mathrm{~mA}$ for $16-18 \mathrm{hr}$. After the gels had been transferred, they were stained to detect any untransferred proteins. The nitrocellulose paper was blocked at $4^{\circ}$ as described by Hossenlopp et al. (1986) and incubated with ${ }^{125}$ I-hIGF-I $\left(2 \times 10^{5} \mathrm{cpm} / \mathrm{ml}\right)$ in $1 \%$ fatty-acid-free bovine serum albumin $-0.1 \%$ Tween 20 in TS (transfer-saline) buffer ( $150 \mathrm{mM} \mathrm{NaCl}, 10 \mathrm{mM}$ Tris- $\mathrm{HCl}, \mathrm{pH}$ $7.4,0.5 \mathrm{mg} / \mathrm{ml}$ sodium azide). The specificity of ${ }^{125} 1$ hIGF-I binding to each IGFBP was assessed by complete displacement of the tracer by the addition of 2.5 $\mu M$ cold hIGF-I to the incubation medium (data not shown). Following this incubation, the membranes were washed and autoradiographed using $\mathrm{X}$-Omat Kodak film and a Dupont intensifying screen, for approximately 3 days. To measure the amount of labeled IGF bound to each IGFBP fraction, the nitrocellulose paper was cut into strips and counted as described by Cortizo and Gagliardino (1991). Based on the known specific activity of the ${ }^{125}$ I-hiGF-I tracer employed we estimated the levels of IGBP assuming a 1:1 relationship between both reactants.

The ${ }^{125}$ I-hIGF-I binding capacity and the affinity constant of the serum were measured by Scatchard analysis. For this purpose, $20 \mu \mathrm{l}$ of toad serum and 10 $\mu l$ of rat serum were incubated for $2 \mathrm{hr}$ at $22^{\circ}$ in the presence of ${ }^{125} \mathrm{I}-\mathrm{hIGF}-\mathrm{I}(20,000 \mathrm{cpm} /$ tube $)$, either with or without the addition of increasing amounts of unlabeled hIGF-I in a total volume of $250 \mu \mathrm{l}$ assay buffer (McCusker et al, 1991). At the end of the incubation period, $250 \mu$ of $0.2 \%$ human immunoglobulin, diluted in the assay buffer, and $0.5 \mathrm{ml}$ of $25 \%$ PEG- 8000 , diluted in water, were added. The mixture was incubated for $10 \mathrm{~min}$ at $4^{\circ}$ and centrifuged ( $3 \mathrm{~min}$ at $8000 \mathrm{~g}$ ); the supernatant was removed and the pellet was washed in $6.25 \%$ PEG- 8000 and centrifuged as before. The radioactivity associated with the pellet was measured by determining the counts per minute of ${ }^{125} \mathrm{I}$ hIGF-I in a well gamma counter. Nonspecific binding was considered as the amount of labeled peptide precipitated in the absence of added IGFBP. The data were analyzed by nonlinear least-squares curves fitting using the LIGAND program (Munson, 1987).

\section{RESULTS}

Serum glucose and protein levels measured in toads were $1.8 \pm 0.1 \mathrm{mM}$ and $45 \pm$ $3 \mathrm{mg} / \mathrm{ml}(n=23)$ respectively. In the rat these values were $6.3 \pm 0.6 \mathrm{mM}$ for glucose levels and $99 \pm 10 \mathrm{mg} / \mathrm{ml}(n=15)$ for protein concentration in serum.
The IGF-I levels in toad serum showed high individual variability ranging from 1.1 to $7.8 \mathrm{ng} / \mathrm{ml}$ with an average of $2.8 \pm 0.5$ $\mathrm{ng} / \mathrm{ml}(n=23)$. These levels were two orders of magnitude lower than those measured in rat serum (Table 1).

To determine the presence of IGFBP in toad and rat serum, different volumes of serum samples were incubated with a constant amount of ${ }^{125}$ I-hIGF-I $\left(6.5 \times 10^{-11}\right.$ $M)$, with and without the addition of $10^{-7}$ $M$ hIGF-I. Figure 2 shows that toad and rat sera bound ${ }^{125}$ I-hIGF-I in a specific manner; smaller volumes of rat than of toad serum were necessary to reach plateaupercentage $\mathrm{SB} / \mathrm{T}$ values (10 vs $25 \mu \mathrm{l})$, this value being higher for the former $(\sim 22 \%)$ than for the latter $(\sim 11 \%)$.

Figure 3 shows displacement curves obtained by incubating a constant volume of toad (a) and rat (b) serum and of ${ }^{125}$ I-hIGF-I together with increasing amounts of cold hIGF-I. In those curves the $\mathrm{EC}_{50}$ values were 0.45 and $1.0 \mathrm{n} M$ for toad and rat serum, respectively.

The Scatchard analysis of such data showed two types of binding sites in both species of serum: one of high affinity-low capacity and another with low affinity-high

TABLE 1

Comparative IGF-I Levels aNd IGFBP Properties of Toad and Rat Serum Samples

\begin{tabular}{|c|c|c|}
\hline Parameter & Toad & Rat \\
\hline $\begin{array}{l}\text { Serum IGF-I levels } \\
\qquad(M)\end{array}$ & $3.6 \times 10^{-10}(23)$ & $8.0 \times 10^{-8}(15)$ \\
\hline $\begin{array}{l}\text { Serum IGF-I levels } \\
(\mathrm{pg} / \mathrm{ml})\end{array}$ & $129 \pm 23(16)$ & $4249 \pm 321(14)$ \\
\hline \multicolumn{3}{|c|}{ Scatchard analysis data } \\
\hline $\begin{array}{l}K_{\mathrm{a}_{1}}\left(M^{-1}\right) \\
R_{1}(M) \\
K_{a_{2}}\left(M^{-1}\right) \\
R_{2}(M) \\
y(\%)\end{array}$ & $\begin{array}{l}1.6 \times 10^{10} \\
1.2 \times 10^{-11} \\
1.9 \times 10^{8} \\
1.9 \times 10^{-10} \\
\quad 13.5\end{array}$ & $\begin{array}{l}3.9 \times 10^{9} \\
8.5 \times 10^{-11} \\
1.5 \times 10^{7} \\
8.8 \times 10^{-9} \\
\quad 3.6\end{array}$ \\
\hline
\end{tabular}

Note. Serum IGF-I levels are expressed in $M$ concentration for the sake of comparison with the Scatchard analysis data. Each value represents the average $\pm S E M$. The number of cases is between parentheses. All of the determinations were performed by triplicates in at least two different assays. $y(\%)$ represents the percentage of IGFBP binding site occupation (fractional occupancy) and was obtained using the equation $y$ $=B / R_{\mathrm{o}} \times 100($ Cuatrecasas et al. 1976$)$. 


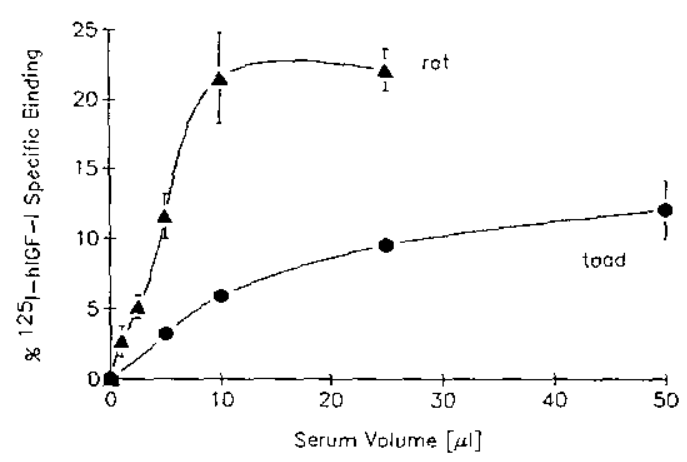

FIG. 2. Specific binding of ${ }^{125}$ I-hIGF-I to different volumes of toad and rat serum. This value was obtained by subtracting at each volume tested the one obtained with the same volume in the presence of $10^{-7}$ $M$ unlabeled hIGF-I. Each point represents the mean \pm SEM of two separate experiments performed in triplicate.

capacity (Figs. $3 \mathrm{c}$ and $3 \mathrm{~d}$ ). The corresponding values for these parameters are listed in Table 1. Toad serum showed a higher apparent affinity at both binding sites $\left(K_{1}\right.$ and $K_{2}$ ) than rat serum did while the number of binding sites were lower in the former than in the latter. The values in Table 1 also show that the percentage fraction of these binding sites occupied by IGF-I is larger in toad than in rat serum.

To further characterize the IGFBP, serum samples of toads and rats were submitted to ligand blot analysis. As it is shown in Fig. 4 , in the toad serum two main bands with $M_{\mathrm{r}}$ of $30-34 \mathrm{kDa}$ were observed, with similar $M_{\mathrm{r}}$ to the IGFBP-1 and IGFBP-2 found in the rat and the IGFBP- 2 in the fetal calf serum. A thin band of $24 \mathrm{kDa}$ and occasionally a diffuse band of $M_{\mathrm{r}} 40 \mathrm{kDa}$ were also detected; the 24-kDa band was similar to the IGFBP-4 detected using the same procedure in rat serum. Thus, according to the ligand blot analysis, an IGFBP with apparent $M_{\mathrm{r}} 30-34 \mathrm{kDa}$ appears as the main carrier for the IGF-1 in toad serum.

Three bands with molecular weights of 40 (IGFBP-3), 30, and $24 \mathrm{kDa}$ were identified in rat serum (Fig. 4), the first being the main component and the last the minor one.

\section{DISCUSSION}

Immunoassayable levels of IGF-I were detected in individual toad serum samples in a range between 1.1 and $7.8 \mathrm{ng} / \mathrm{ml}$. Wider variations were reported by other authors who have measured IGF-I in pooled serum of various anuran species (Daughaday et al., 1985; Pancak-Roesler and Lee, 1990); furthermore it has been reported that serum IGF-I levels in toad undergo circannual variations (Pancak-Roesler and Lee, 1990). Plasma protein also has circannual variations but with an otherwise uneven distribution of peak and trough values (Robertson, 1986). Therefore, each rhythm might be under the control of a different synchronizer. Such variations do not explain the fluctuations we are reporting since all the blood sampling was performed at one season. Hence, our differences might represent individual variations of the serum hormone levels.

Using the same IGF-I antibody as we do, Pancak-Roesler and Lee (1990) have shown that after acid-ethanol treatment, toad and human plasma and purified human IGF-I standards gave parallel displacement curves. The $81 \%$ homology of the amino acid sequence of the primary IGF-I translation product of amphibian (Xenopus laevis) with the one corresponding to hIGF-I might support those results, (Kajimoto and Rotwein, 1990). Although this parallelismwhich we have confirmed-and the above mentioned hormone-molecular homology grant validity to the comparison of relative IGF-I serum levels, there is no certainty regarding the real absolute values since the standard employed in the immunoassays was hIGF-I. To avoid this problem, other authors have expressed the hormone values as nanograms of equivalents of hIGF-I (Daughaday et al., 1985; Pancak-Roesler and Lee, 1990). Despite this fact, it seems to be that IGF-I levels measured in toads are 50 to 200 times lower than those re- 

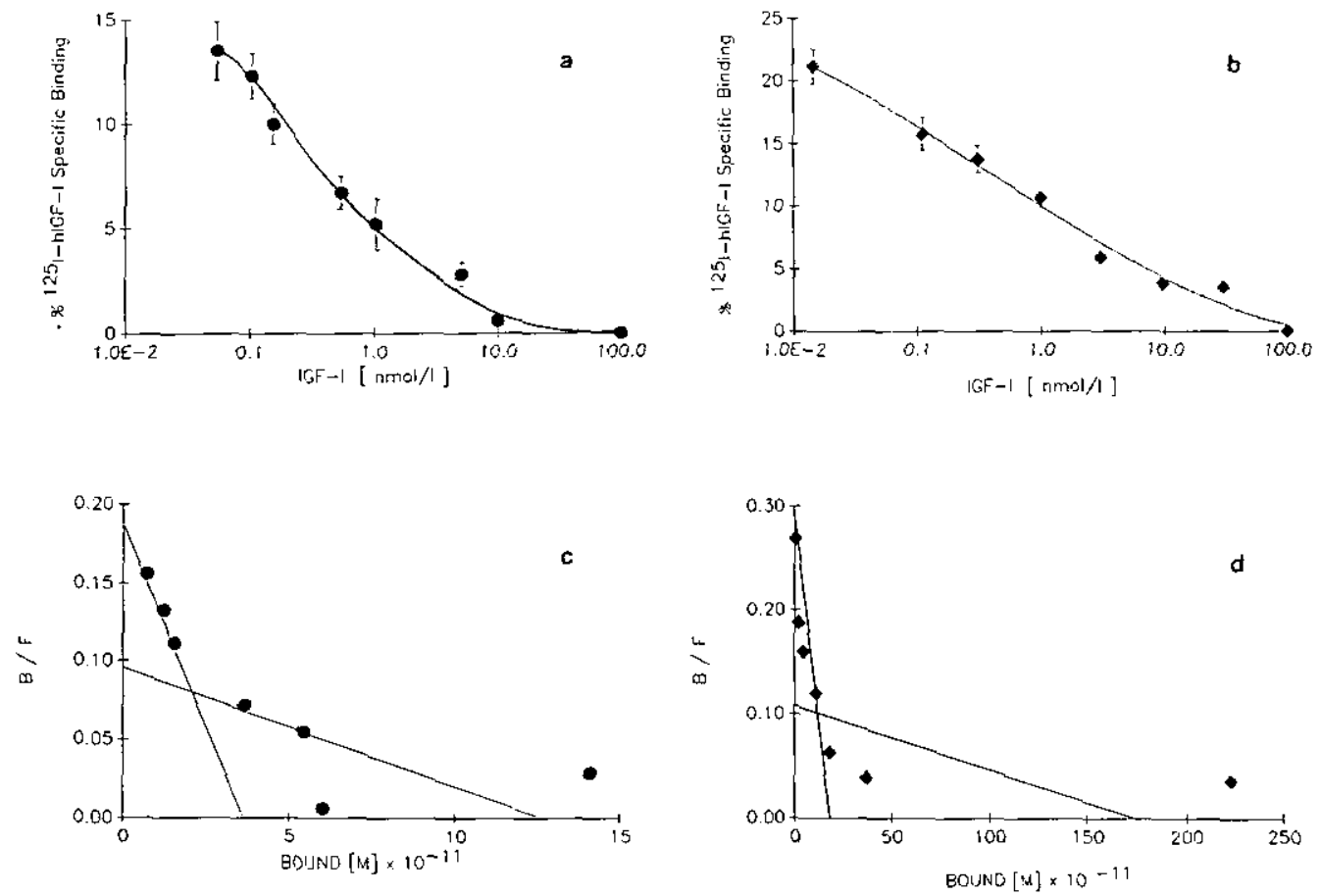

FIG. 3. Displacement of ${ }^{125}$ I-hlGF-I binding to $20 \mu$ l of toad serum (a) and $10 \mu$ of rat serum (b) by different concentrations of unlabeled IGF-I. Specific binding represents the value obtained by subtracting at each hormone concentration the value obtained in the presence of $10^{-7}$ unlabeled hIGF-I and expressed as a percentage of the total count. Scatchard analysis of the data represented in a and $b$ are plotted in $c$ (toad) and $d$ (rat).

ported in human (Ranke et al., 1988) and rat (Yang et al., 1989) serum. In this regard, it must be considered that other components of the toad serum such as glucose and protein levels measured by ourselves and by other authors are also significantly lower than those found in mammals (Robertson, 1986; Miller, 1960). These data would suggest that, in amphibians, the hormonemetabolic homeostasis set point is set at a lower value than in mammals.

The presence of IGFBP in toads was initially reported by Daughaday et al. (1985) using ${ }^{125}$ I-IGF-II as a tracer and gel filtration for its determination. According to these authors, the bound tracer to the serum protein fractions was not displaced by added unlabeled IGF-II and consequently was considered nonspecific. Pancak-
Roesler and Lee (1990) later reported that most of IGF immunoreactivity in anuran plasma was associated with an aciddissociable high-molecular-weight fraction. Using size exclusion chromatography for its separation from the other serum proteins and labeled recombinant hIGF-I for its identification, they conclude that the IGFBP might have a molecular weight of $\sim 50$ to $60 \mathrm{kDa}$. Our results confirm the presence of IGFBP in the toad serum, however, and probably due to the different methodology employed-ligand blot instead of size exclusion chromatographyour results do not fully agree with those previously reported. Using ${ }^{125}$ I-hIGF-I in a Western ligand blot procedure Kelly and Siharat would have obtained. comparable results to our own in the plasma of the bull- 


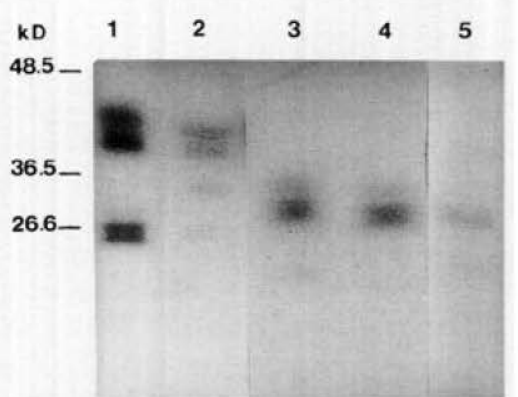

Fug. 4. Ligand blot of toad serum. Thirty microliters of toad serum was electrophoresed through a 12.5\% nonreduced SDS-PAGE, electroblotted to nitrocellulose paper, and incubated with ${ }^{125}$ l-hIGF-I. The $M_{r}$ of each IGFBP was estimated by comparison to prestained molecular weight marker proteins. Each lane represents: (1) $5 \mu$ l of rat serum, (2) $2 \mu$ l of human serum, (3) $5 \mu$ l of human serum, (3 and 4), $30 \mu$ l of toad serum, and (5) $5 \mu l$ of fetal calf serum.

frog: binding bands between 25 and $50 \mathrm{kDa}$ (data quoted in the paper of Bern et al., 1991).

In toad serum we have identified IGFBP fractions with $M_{\mathrm{r}}$ similar to the ones reported in mammals (Yang et al., 1989) but with an otherwise different distribution. In fact, two bands with 30-34 kDa appeared as the main serum IGF carrier together with a light fraction of $24 \mathrm{kDa}$. Occasionally, a third diffuse band of $40 \mathrm{kDa}$ was also detected. This IGFBP pattern contrasts with the one corresponding to rat-and also with human-serum, where the 40-kDa fraction represents the main component. Negative results were obtained when IGFBP-3 proteolysis was studied in toad serum using ${ }^{125}$ I-IGFBP-3 as described by Lamson $e t$ al. (1991) (data not shown). Hence, the infrequent appearance of such low IGFBP-3 levels found in toad serum might be genuine and characteristic of this species rather than the consequence of self-degradation during handling procedures.

The displacement curves performed using whole serum samples, labeled and unlabeled hIGF-I, demonstrate the specificity of the binding of the toad serum IGFBP as well as its properties. The latter were comparable to those we have simultaneously measured in the rat serum, being the first experimental evidence reported on this matter.

A rough estimate of the IGF carrier levels (IGFBPs) measured in our laboratory in samples of rat and toad serum indicates that in the latter, the figures were almost 33 times lower than those in the former. The values for binding capacity measured in the sera of these species were also higher in rats than in toads. Thus, with the concerns already mentioned regarding absolute serum levels of IGF in the toad, these levels together with the differences recorded in the number of IGF-I binding sites, their affinity constants and their percentage of occupancy might indicate an uneven relationship between the fraction of free and bound IGF-I in the serum of toads and rats as previously suggested by Daughaday et al. (1985). According to these authors this fact might explain the relatively greater biological activity of nonmammalian serum in bioassays than in receptor and immunoassays (Shapiro and Pimstone, 1977; Wilson and Hintz, 1982). This assertion remains to be confirmed as well as its possible physiological significance.

Altogether our data provides new evidence of the presence and the properties of IGFBP in amphibians, confirming its wide distribution among different species and its possible role as modulators of the IGF-I biological effects.

\section{ACKNOWLEDGMENTS}

The authors thank Lic. Flavio Francini for technical assistance in the obtention of blood samples and Miss Nyria Fenoglio for secretarial support. This work was partially supported with funds provided by CONICET.

\section{REFERENCES}

Bern, H. A., Mc Cormick, S. D., Kelley, K. M., Gray, E. S., Nishioka, R. S., Madsen, S. S., and 
Tsai, P. I. (1991). Insulin-like growth factors "under water": Role in growth and function of fish and other poikilothermic vertebrates. In "Modern Concepts of Insulin-like Growth Factors" (E. M. Spencer, Ed.), pp. 85-96. Elsevier, Amsterdam/ New York.

Bowsher, R., Wei-Hua, L., Apathy, J., O'Brien, D., Ferguson, A., and Henry, D. (1991). Measurement of insulin-like growth factor II in physiological fluids and tissue. I. An improved extraction procedure and radioimmunoassay for human and rat fluids. Endocrinology 128, 805-814.

Bradford, M. M. (1976). A rapid and sensitive method for quantification of micrograms quantities of protein utilizing the principle of protein-dye binding. Anal. Biochem. 72, 248-254.

Cortizo, A. M., and Gagliardino, J. J. (1991). Protein glycation: Its role in the changes induced by diabetes in the properties of the serum insulin-like growth factor-I binding proteins. J. Endocrinol. 131, 33-38.

Cuatrecasas, P., and Hollenberg, M. D. (1976). Membrane receptors and hormone action. Adv. Protein Chem. 30, 251-451.

Daughaday, W. H., Kapadia, M., Yanow, C. E., Fabrick, K., and Mariz, I. K. (1985). Insulin-like Growth Factors I and II of Nonmammalian Sera. Gen. Comp. Endocrinol. 59, 316-325.

D'Ercole, A. J., Underwood, L. E., Van Wyk, J. J., Decedue, C. J., and Foushee, D. B. (1976). Specificity, topography and ontogeny of the somatomedin $\mathrm{C}$ receptor in mammalian tissues. In "Growth Hormone and Related Peptides" (A. Pecile and R. Muller, Eds.). Excerpta Medica, Amsterdam.

Flier, J. S., Usher, P., and Moses, A. C. (1986). Monoclonal antibody to the Type I insulin-like growth factor (IGF-I) receptor-mediated DNA synthesis: Clarification of the mitogenic mechanism of IGF-I and insulin in human skin fibroblasts. Proc. Natl. Acad. Sci. USA 83, 664-668.

Furlanetto, R. W., Underwood, L. E., Van Wyk, J. J., and D'Ercole, A. J. (1977). Estimation of somatomedin-C levels in normals and patients with pituitary disease by radioimmunoassay. $J$. Clin. Invest. 60, 648-657.

Hossenlopp, P., Seurin, D., Segovia-Quinson, B., Hardouin, S., and Binoux, M. (1986). Analysis of serum insulin-like growth factor binding protein using Western blotting: use of the method for titration of the binding and competitive binding studies. Ann. Biochem. 154, 138-143.

Kajimoto, Y., and Rotwein, P. (1990). Evolution of insulin-like growth factor I (IGF-I): Structure and expression of an IGF-I precursor from Xenopus laevis. Mol. Endocrinol. 4, 217-226.

Laemmli, U. K. (1970). Cleavage of structural proteins during the assembly of the head of bacteriophage T4. Nature 227, 680-685.

Lamson, G., Giudice, L. C., and Rosenfeld, R. G. (1991). A simple assay for proteolysis of IGFBP3. J. Clin. Endocrinol. Metab. 72, 1391-1393.

McCusker, R. H., Busby, W. H., Dehoff, M. H., Camacho-Hubner, C., and Clemmons, D. R. (1991). Insulin-like growth factor (IGF) binding to cell monolayers is directly modulated by the addition of IGF-binding proteins. Endocrinology 129, 939949.

Miller, M. R. (1960). Pancreatic islet histology and carbohydrate metabolism in amphibians and reptiles. Diabetes 9, 318-323.

Munson, P. J. (1987). "Ligand: Data Analysis and Curve-Fitting for Ligand Binding Experiments."

Pancak-Roesler, M. K., and Lee, P. D. K. (1990). Insulin-like growth factor-I and insulin-like growth factor-binding protein in the Toad, Bufo woodhousei. Gen. Comp. Endocrinol. 78, 263-272.

Ranke, M. B., Blum, W. F., and Bierich, J. R. (1988). Clinical relevance of serum measurements of insulin-like growth factors and somatomedin binding proteins. Acta Paediatr. Scand. Suppl. 347, 114-126.

Rechler, M. M., and Nissley, S. P. (1990). Insulin-like growth factors. In "Handbook of Experimental Pharmacology" (M. B. Sporn and S. B. Roberts, Eds.), Vol. 95. Springer-Verlag, Heidelberg.

Robertson, D. R. (1986). Plasma ionic calcium regulation by anuran parathyroid glands. Comp. Biochem. Physiol. A 85, 359-369.

Rodbard, D. (1984). Lessons from the computerization of radioimmunoassays: An introduction to the basic principles of modeling. In "Computers in Endocrinology" (D. Rodbard and G. Forti, Eds.), pp. 75-99. Raven Press, New York.

Rutanen, E. M. (1990). Insulin-like growth factors and their binding proteins. Acta Endocrinol. (Copenhagen) 123, 7-13.

Shapiro, B., and Pimstone, B. L. (1977). A phylogenetic study of sulphation factor activity in 26 species. J. Endocrinol. 74, 129-135.

Swenne, I., and Hill, D. J. (1989). Growth hormone regulation of DNA replication, but not insulin production, is partially mediated by somatomedin-C/ insulin-like growth factor $I$ in isolated pancreatic islets from adult rats. Diabetologia 32, 191-197.

Van Wyk, J. J. (1984). The somatomedins: biological 
actions and physiologic control mechanism. In "Hormonal Proteins and Peptides" (Choh Hao Li, Ed.), pp. 81-125.

Wilson, D. M., and Hintz, R. L. (1982). Inter-species comparison of somatomedin structure rising immunological probes. J. Endocrinol. 95, 59-64.

Yang, Y. W.-H., Wang, J.-F., Orlowski, C. C., Nissley, S. P., and Rechler, M. M. (1989). Structure, specificity and regulation of the insulin-like growth factor binding proteins in adult rat serum. Endocrinology 125, 1540-1555.

Yateman, M. E., Clappey, D. C., Cwjfan Hughes, S. C., Frost, V. J., Wass, J. A. H., and Holly, J. M. P. (1993). Cytokines modulate the sensitivity of human fibroblasts to stimulation with insulin-like growth factor-I (IGF-I) by altering endogenous IGF-binding protein production. J. Endocrinol. 137, 151-159. 